\title{
MANAJEMEN KOMUNIKASI \\ PROGRAM CORPORATE SOCIAL RESPONSIBILITY (CSR) KAMPUNG GAMBUT BERDIKARI PT. PERTAMINA RU II SUNGAI PAKNING KABUPATEN BENGKALIS
}

\author{
${ }^{1}$ Nova Yohana, ${ }^{2}$ Yasir, ${ }^{3}$ Evawani, ${ }^{4}$ Nurjanah \\ 1,2,3,4 Jurusan Komunikasi, Fakultas Ilmu Sosial dan Ilmu Politik, Universitas Riau \\ nova.yo7@gmail.com
}

Diterima : 08 Desember 2020; Review : 03 Januari 2021; Direvisi Author : 20 Januari 2021; Terbit : 14 Februari 2021

\begin{abstract}
Abstrak
Kampung Gambut Berdikari merupakan salah satu tema besar program CSR PT. Pertamina RU II Sungai Pakning. Melalui program Kampung Gambut Berdikari, perusahaan berupaya merestorasi lingkungan sekaligus memberdayakan masyarakatnya secara berkelanjutan terutama pada lahan gambut di wilayah Riau yang rentan terbakar. Tujuan penelitian ini adalah untuk mengetahui manajemen komunikasi PT Pertamina RU II Sungai Pakning dalam program CSR "Kampung Gambut Berdikari" di wilayah operasi perusahaan. Metode penelitian ini menggunakan metode kualitatif. Penentuan informan dilakukan secara purposif. Teknik pengumpulan data dilakukan dengan wawancara mendalam, observasi dan dokumentasi. Hasil penelitian menunjukkan bahwa ,pada tahap perencanaan dilakukannya proses social mapping dan penyusunan rencana kerja hingga rencana strategis dan menghasilkan output yaitu program Kampung Gambut Berdikari. Pengorganisasian dan pelaksanaan program, dilakukan oleh CDO (Community Development Officer) melalui analisis dan keluaran kebijakan perusahaan kepada masyarakat sasaran sesuai dengan kriteria penerima yang telah ditetapkan. Pesan yang disampaikan oleh CDO disalurkan melalui media formal, media sosial instagram, koran, portal berita serta laporan kinerja tahunan. Monitoring dan evaluasi komunikasi dilaksankan dengan monev internal pada saat program berjalan (ongoing review) yang dilakukan per tiga bulan dan monev eksternal dilakukan saat program telah melalui setahun berjalan. Manajemen komunikasi yang dilakukan berjalan dengan baik.
\end{abstract}

Kata Kunci : Manajemen Komunikasi, Program CSR, Kampung Gambut Berdikari, Pemberdayaan Masyarakat

\section{LATAR BELAKANG}

Dewasa ini, isu kedermawanan sosial perusahaan mengalami perkembangan pesat sejalan dengan berkembangnya konsep tanggung jawab sosial perusahaan (Corporate Social Responsibility). Salah satu ide pokoknya terkait dengan mandat dunia usaha untuk tidak semata-mata mencari keuntungan, tetapi harus pula bersikap etis dan berperan dalam penciptaan investasi sosial. Diantaranya, yang lazim dilakukan oleh perusahaan 
adalah menyelenggarakan program pengembangan dan pemberdayaan masyarakat serta kegiatan karitas (Nursahid, 2006).

Dunia usaha bukan lagi sekedar kegiatan ekonomi untuk menciptakan profit demi kelangsungan usahanya, melainkan juga mempunyai tanggung jawab terhadap sosial dan lingkungannya. Diyakini bahwa CSR merupakan investasi bagi perusahaan demi pertumbuhan dan keberlanjutan (sustainability) perusahaan. Artinya CSR bukan lagi dilihat sebagai sentra biaya (cost center) melainkan sebagai sentra laba (profit center) dimasa mend atang (Wibisono, 2007).

PT. Pertamina sebagai perusahaan energi nasional di Indonesia, juga ikut serta mengimplementasikan program CSR sebagai wujud komitmen untuk senantiasa memprioritaskan keseimbangan dan kelestarian alam, lingkungan dan masyarakat. Dengan menyejahterakan manusia, alam, dan lingkungan, maka Pertamina akan mampu mencapai pertumbuhan bisnis yang berkelanjutan. Begitu halnya dengan PT. Pertamina RU II Sungai Pakning yang mengimplementasikan program CSR untuk permberdayaan masyarakat yang berkelanjutan melalui program Kampung Gambut Berdikari.

Ide besar program CSR mengenai Kampung Gambut Berdikari sendiri berawal karena masalah serius yang dulu kerap dialami oleh Provinsi Riau, yakni kebakaran lahan dan hutan salah satunya yang terjadi di Kelurahan Sungai Pakning dan sekitarnya di Kecamatan Bukit Batu Kabupaten Bengkalis. Tanah Gambut yang menjadi mayoritas lahan juga mulai dibakar oleh warga untuk dijadikan lahan kosong yang siap dijadikan ladang produksi. Akibat pembakaran gambut ini resapan air dalam gambut berkurang dan menjadikanya mudah terbakar ketika musim kering. Melihat masalah yang kian serius ini PT. Pertamina RU II mencoba memberikan solusi yakni dengan memberikan bantuan-bantuan melalui program-program CSR atau Corporate Social Rensponsibility.

Merujuk pada tema besar Program CSR "Kampung Gambut Berdikari”, PT. Pertamina RU II Sungai Pakning mencoba membuat program-program yang lebih bersifat pencegahan kebakaran lahan dan hutan daripada memadamkan. Lewat program Kampung Gambut Berdikari CSR PT. Pertamina RU II Sungai Pakning berusaha merubah mindset lahan gambut 
yang sebelumnya dikenal sebagai sumber bencana kabut asap juga memiliki potensi ekonomi yang dapat mensejahterakan masyarakat lokal dengan memberdayakan UMKM setempat apabila dikelola secara baik dan berkelanjutan. Program restorasi yang digagas Pertamina tersebut tidak hanya menyentuh pemulihan lingkungan saja, tetapi juga pemberdayaan masyarakat. Program CSR "Kampung Gambut Berdikari" diharapkan dapat menjadi jembatan untuk menciptakan sumber daya manusia yang lebih baik lagi dan melestarikan sumber daya alam atau ekosistem yang ada. Dengan programprogram pemberdayaan yang ada pula dapat meningkatkan kesejahteraan baik dari segi ekonomi, sosial maupun kesehatan masyarakat di sekitar tempat operasi Perusahaan.

Proses komunikasi program CSR Kampung Gambut Berdikari dilaksanakan oleh PT. Pertamina RU II Sungai Pakning secara terpadu dan sinergi dengan masyarakat di sekitar tempat operasi perusahaan. Manajemen komunikasi dilakukan oleh pihak CSR PT Pertamina RU II Sungai Pakning sejak dari perencanaan (planning) hingga evaluasi (evaluation). Manajemen komunikasi adalah pilar utama keberhasilan program sehingga sesuai dengan yang diharapkan oleh semua pihak. Manajemen komunikasi yang dilakukan adalah planning (perencanaan), organizing (pengorganisasian), actuating (pelaksanaan), monitoring (pengawasan) dan evaluating (evalusi) kegiatan komunikasi.

Keberhasilan kegiatan komunikasi banyak ditentukan oleh manajemen komunikasi yang diterapkan. Di lain pihak jika tidak ada manajemen komunikasi yang baik, efek dari proses komunikasi bukan tidak mungkin akan menimbulkan pengaruh negatif. Manajemen komunikasi yang baik dalam suatu organisasi akan menentukan tingkat keberhasilan dari organisasi tersebut dalam mencapai target dan sasaran. Manajemen komunikasi akan mengarahkan cara dan pola komunikasi kepada orang-orang yang berada di dalam organisasi (internal) dan orang-orang yang memungkinkan akan terlibat dalam aktivitas organisasi (eksternal).

Berdasarkan pemaparan diatas, maka penelitian ini dilaksanakan dengan tujuan untuk mengetahui manajemen komunikasi program CSR (Corporate Social Responsibility) Kampung Gambut Berdikari PT Pertamina RU III Sungai Pakning Kabupaten Bengkalis. 


\section{METODOLOGI PENELITIAN Manajemen Komunikasi}

Manajemen komunikasi
manajemen yang diterapkan
kegiatan komunikasi. Ini
manajemen akan berperan atau sebagai
penggerak aktivitas komunikasi dalam
usaha pencapaian tujuan komunikasi.
Manajemen komunikasi adalah ilmu yang mempelajari bagaimana mengelola informasi untuk mencapai tujuan (Suprapto, 2009: 144). Setiap aktivitas pendistribusian pesan dan atau informasi adalah aktivitas komunikasi. Secara umum, definisi manajemen komunikasi adalah proses pengelolaan sumberdaya komunikasi yang ditujukan untuk meningkatkan kualitas dan efektivitas pertukaran pesan yang terjadi dalam berbagai konteks komunikasi (individual, organisasional, govermental, sosial, atau internasional).

Menurut Harry Irwin (dalam Soedarsono, 2009: 46), manajemen komunikasi merupakan proses yang menggunakan manusia, keuangan dan sumber teknik yang berfungsi membentuk komunikasi antarperusahaan dan antara perusahaan dengan publiknya. Sedangkan Michael Kaye (dalam Soedarsono, 2009:46) memberikan pengertian manajemen komunikasi menyiratkan penggunaan sumber daya manusia dan teknologi secara optimal untuk menjalin hubungan antarmanusia.Kedua pengertian manajemen komunikasi tersebut pada hakikatnya mengusulkan agar individu dapat mengoptimalkan sumber dayanya ke dalam aspek pengelolaan manajemen di organisasi/ perusahaan dengan menggunakan model komunikasi yang sistematis sehingga memudahkan aktivitas komunikasi manajemen di seluruh unit organisasi/ perusahaan.

.Dalam hal ini, para pelaku komunikasi setidaknya harus mengetahui seluk-seluk ilmu manajemen dan ilmu komunikasi.Apabila ada keinginan bersama untuk menyukseskan penyelenggaraan komunikasi secara efektif.Adapun perpaduan ilmu manajemen (pendekatan model input-output dari Henry Fayol) dan ilmu komunikasi (pendekatan model komunikasi matematik dari Shanon \& Weaver), dapat dijabarkan dalam gambar model berikut ini : 


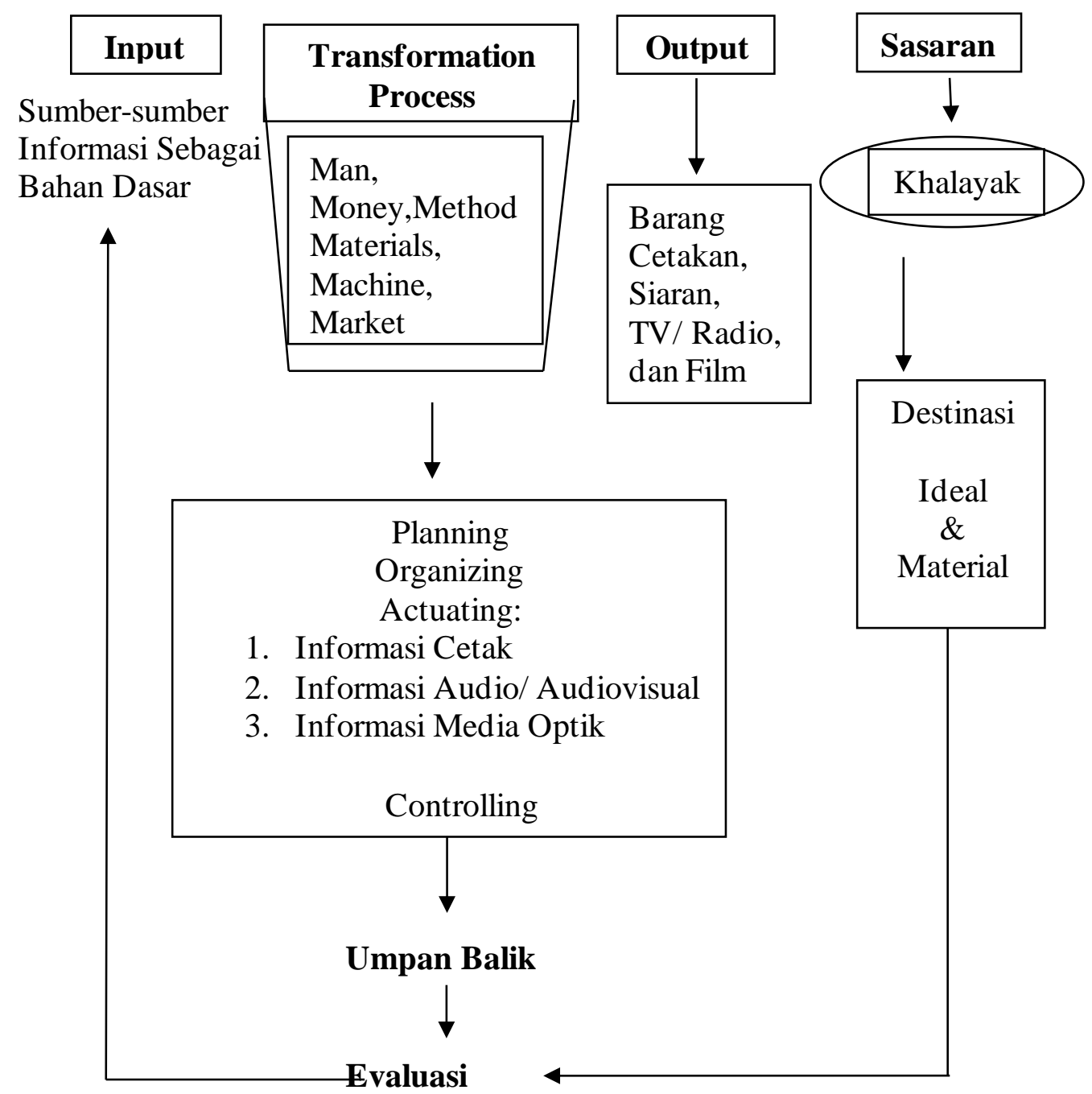

Gambar 2.1.Model Input-Output dan Model Proses Komunikasi Sumber : (Tommy Suprapto, 2009: 141)

\section{Corporate Social Responsibility (CSR)}

\section{Corporate Social Responsibility}

(CSR) merupakan suatu komitmen berkelanjutan oleh dunia usaha untuk bertindak etis dan memberikan kontribusi kepada pengembangan ekonomi dari komunitas setempat ataupun masyarakat luas, bersaman dengan peningkatan taraf hidup pekerja beserta keluarganya
(Wibisono, 2007:7). Menurut Christine A Hemingway\& Patrick W Maclagan (2004, 33-44). Corporate Social Responsibility requires companies to acknowledge that they should be publicy accountable not only for their financial performance but also for their social and environmental record. More widely, CSR encompasses the extent to which companies should promote 
human rights, democracy, community improvement and sustainable development objectives throught the world. (The Confederation of British Industry)

Dalam penelitian ini, terkait kemitraan antara perusahaan dengan pemerintah, diharapkan kedua belah pihak mendapatkan manfaat dari tanggungjawab sosial yang dilakukan oleh perusahaan.

\section{Pemberdayaaan Masyarakat}

Proses pemberdayaan masyarakat (community empowerment) merupakan upaya membantu masyarakat untuk mengembangkan kemampuannya sendiri sehingga bebas dan mampu untuk mengatasi masalah dan mengambil keputusan secara mandiri. Proses pemberdayaan teersebut dilakukan dengan memberikan kewenangan (power), aksesibilitas terhadap sumberdaya dan lingkungan yang akomodatif (Pekins dan Zimmerman, 1995). Konsep pemberdayaan telah mewarnai paradigma pembangunan. Pada tataran kehidupan bernegara, pemberdayaan dimaknai sebagai partisipasi yang setara antara pemerintah, swasta dan masyarakat (Syahyuti, 2006).

Dengan demikian, pemerintah, swasta, dan masyarakat memiliki tanggung jawab yang sama dalam upaya pencapaian tujuan pembangunan. Pemerintah sebagai institusi formal berperan dalam perencanaan dan pelaksanaan pembangunan di segala sektor. Swasta dapat berperan sebagai patner pemerintah dalam pelaksanaan pada satu atau beberapan sektor pembangunan. Masyarakat harus berperan sebagai subyek dan obyek pembangunan dengan pengertian bahwa masyarakat harus dilibatkan dalam perencanaan, pelaksanaan, melakukan evaluasi dan menikmati hasil-hasil pembangunan. Dari berbagai pandangan mengenai konsep pemberdayaan, maka dapat disarikan, bahwa pemberdayaan ekonomi masyarakat adalah penguatan kepemilikan faktorfaktor produksi, penguatan penguasaan distribusi dan pemasaran, penguatan masyarakat untuk mendapatkan gaji/upah yang memadai, dan penguatan masyarakat untuk memperoleh informasi, pengetahuan dan ketrampilan yang harus dilakukan secara multi aspek baik dari aspek masyarakatnya sendiri maupun aspek kebijakannya.

Damanhuri dalam Suparjan dan Hempri (2013) menyatakan bahwa pemberdayaan ekonomi rakyat merupakan salah satu elemen strategis dalam paradigma baru pembangunan. Bila ekonomi rakyat berkembang, maka 
pendapatan dan kesejahteraan rakyat akan meningkat sebab kebutuhan ekonomi mereka semakin terpenuhi. Dengan pemberdayaan ekonomi rakyat maka partisipasi aktif dalam pembangunan akan menjadi pendorong dari dalam (inner drive). Bila partisipasi aktif masyarakat dalam pembangunan meningkat maka tujuan akhir pembangunan akan lebih mudah.

Banyak pendekatan metodologis dijelaskan dalam hal jenis analisis yang dilakukan, dapat dilihat dari daftar referensi dalam bentuk data sekunder yang dibentuk berdasarkan historis kajian, arsip, dokumen untuk melengkapi pendekatan teoritikal (Rorong,2019:94).

Penelitian ini menggunakan metode kualitatif dengan perspektif manajemen komunikasi menggunakan pendekatan studi kasus eksploratif. Menurut Kaye (1994) manajemen komunikasi lahir karena adanya tuntutan untuk menjembatani antara teoritisi dengan praktisi komunikasi. Perspektif manajemen yang digunakan adalah pengaruh sosial, menekankan pada pentingnya penerapan fungsi-fungsi manajemen komunikasi dan memiliki fokus perhatian pada perubahan (pendapat, sikap, kepercayaan dan perilaku).
Informan dalam penelitian ini yakni: 1) pelaksana program CSR Kampung Gambut Berdikari PT. Pertamina RU II Sungai Pakning, 2) representasi masyarakat di Sungai Pakning Kabupaten Bengkalis yang terlibat dalam kegiatan program CSR Kampung Gambut Berdikari. Informan subjek dipilih secara purposif sesuai kebutuhan data dari penelitian ini, sebagai sumber informasi dan dianggap mengetahui permasalahan perlindungan anak secara mendetail. Teknik pengumpulan data dilaksanakan dengan melakukan wawancara mendalam, observasi dan dokumentasi. Temuan dalam penelitian ini dianalisis dengan komponen analisis data yang dikembangkan oleh Miles dan Huberman, yang terdiri atas tiga subproses yang saling terkait, yaitu: reduksi data, penyajian data serta penarikan kesimpulan dan verifikasi. Teknik keabsahan data dilakukan melalui triangulasi dan perpanjangan keikutsertaan.

\section{HASIL DAN PEMBAHASAN}

Program CSR "Kampung Gambut Berdikari” yang dilakukan oleh PT. Pertamina (Persero) RU II Sungai Pakning telah mulai diimplementasikan sejak tahun 2017. Sesuai dengan slogan yang selalu diunggulkan oleh BUMN yakni "Hadir Untuk Negeri”, PT. Pertamina (Persero) 
RU II Sungai Pakning sebagai salah satu BUMN terbesar di Indonesia berusaha untuk turut serta merealisasikan slogan tersebut. Salah satunya dengan mematuhi UU No 40 tahun 2007 tentang CSR pada Perseroan Terbatas yang ranah usahanya berkaitan dengan sumber daya alam.

Merujuk pada tema besar Program CSR “Kampung Gambut Berdikari”, PT. Pertamina RU II Sungai Pakning mencoba mengentaskan permasalahan kebakaran hutan dan lahan yang kerap terjadi setiap tahunnya. PT. Pertamina RU II Sungai Pakning menyadari upaya pemulihan lingkungan yang dalam hal ini yaitu pengembalian fungsi ekologi lahan gambut sejatinya tidak dapat dilakukan secara parsial oleh korporasi saja, akan tetapi agar yang hasilnya maksimal serta memberikan dampak luas juga harus melakukan pemberdayaan masyarakat (community development). Dengan melibatkan masyarakat pada program restorasi maupun pemulihan, dan pelestarian lahan gambut maka akan muncul kesadaran untuk ikut terlibat dalam program yang akan dijalankan. Masyarakat akan turut serta dalam pelestarian dan pemeliharaan gambut, seiring dengan peningkatkan kesejahteraan mereka. Oleh karena itu program Kampung Gambut Berdikari berupaya untuk mengintegrasikan antara pemulihan lingkungan dan pemberdayaan masyarakat setempat (community development). Selain itu lewat program ini PT. Pertamina RU II Sungai Pakning ingin melakukan gebrakan dengan mindset masyarakat umum bahwa gambut yang kerap dianggap sebagai sumber masalah sejatinya dapat menjadi bermanfaat dan meningkatkan perekonomian masyarakat.

Penelitian di lapangan menunjukkan bahwa sejauh ini pelaksanaan program CSR yang dilakukan PT. Pertamina RU II Sungai Pakning dapat dikatakan baik. Hal ini terlihat dari berbagai penghargaan yang telah diraih oleh perusahaan. Keberhasilan sebuah program tentu didukung oleh manajemen komunikasi yang baik telah mampu diciptakan oleh PT. Pertamina RU II Sungai Pakning.

Hal menarik lainnya dalam menjalankan program kampung gambut berdikari, PT. Pertamina RU II Sungai Pakning tidak hanya fokus pada upaya penangan teknis pemadaman pada saat kebakaran hutan dan lahan terjadi, akan tetapi mencoba membuat kelompok binaan yang lebih bersifat pencegahan mulai penambahan peralatan pemadaman, pembentukan Forum Komunikasi Masyarakat Peduli Api (Forkompa), 
hingga hal teknis berkaitan dengan pelatihan pemadaman. Selain itu, pemanfaatan lahan bekas terbakar juga dilakukan, melalui pertanian budidaya nanas dan diservikasi pengolahan produk, lewat program ini juga dilakukan pengembangan hutan gambut menjadi Arboretum Gambut pertama di Sumatera dan menjadikannya sebagai sarana eduwisata yang dikelola masyarakat. Bahkan Pertamina juga membina sembilan sekolah dasar di Kecamatan Bukit Batu dengan menanamkan nilai-nilai kampung gambut berdikari sejak usia dini. Implementasinya, kesembilan sekolah dasar tersebut memiliki kurikulum berbasis lingkungan yang mengangkat isu-isu pencegahan kebakaran lahan dan hutan serta pemanfaatan potensi wilayah gambut.

Secara lebih rinci, berikut penulis jabarkan model manajemen komunikasi program CSR kampung gambut berdikari PT. Pertamina RU II Sungai Pakning, Kabupaten Bengkalis mulai dari analisis perencanaan, analisis bentuk komunikasi departemen community development officer dalam pengorganisasian (organizing) dan pelaksanaan (actuating) hingga pelaksanaan monitoring dan evaluasi komunikasi terhadap program.

\section{Analisis Perencanaan (planning) Komunikasi Program CSR Kampung Gambut Berdikari PT. Pertamina RU II Sungai Pakning Kabupaten Bengkalis}

Perencanaan mencakup penetapan tujuan dan standar, penentuan dan prosedur, pembuatan rencana serta prediksi yang akan terjadi. Melalui perencanaan, pemimpin akan mengidentifikasi hasil kerja yang diinginkan serta mengidentifikasi caracara mencapainya (Suprapto, 2011: 131). Menurut Cangara perencanaan komunikasi merupakan suatu usaha sistematis dan kontinu dalam mengorganisasikan usaha aktivitas manusia terhadap suatu upaya penggunaan sumber daya komunikasi secara efisien guna merealisaikan kebijakan komunikasi (Cangara dalam Purnaningtyas, N. C., \& Rina, N, 2018: 20). Sumber daya yang dimaksud tidak saja melibatkan media massa namun lebih spesifik lagi juga mencakup komunikasi antarpribadi yang secara khusus dirancang untuk mengubah perilaku dan membentuk keterampilan tertentu dalam menjalankan tugas yang dibebankan oleh organisasi (John Middleton dalam Cangara, 2014).

PT. Pertamina RU II Sungai Pakning sebagai Badan Usaha Milik Negara yang melangsungkan kerja didaerah dan 
ditengah masyarakat, menyadari bahwa punya andil dan kewajiban yang harus ditunaikan kepada masyarakat. Lewat program perencanaan program CSR nya PT. Pertamina RU II Sungai Pakning ingin turut serta mengambil peran dalam penyelesaian masalah-masalah komunitas atau masyarakat disekitarnya.

Tahap perencanaan komunikator pada program secara umum dilakukan bidang CDO (Community Development Officer) yang menjadi pembina dalam pengawas dalam pelaksanaan program. Selain itu juga dilakukan perencanaan program kelompok binaan melalui rapat yang dilakukan antar anggota kelompok yang dipimpin langsung oleh ketua kelompok.

Perencanaan program CSR kampung gambut berdikari PT. Pertamina RU II Sungai Pakning melakukan 2 langkah utama yaitu lewat FGD dan Social Mapping antara UPK (Unit Pengelolan Kegiatan) dan perwakilan dari masyarakat. Selanjutnya riset social mapping atau pemetaan sosial di wilayah ring 1. Dari hasil social mapping baik dilihat dari segi sosial, ekonomi, lingkungan dan kesehatan masih banyak keterkaitan dengan akibat dari kebakaran hutan dan lahan. Rendahnya kesadaran untuk tidak membakar lahan gambut ketika membuka lahan baru juga masih sangat rendah.

\section{Analisis Bentuk Komunikasi dalam Pengorganisasian dan Pelaksanaan Program CSR Kampung Gambut Berdikari PT. Pertamina RU II Sungai Pakning Kabupaten Bengkalis}

Pengorganisasian merupakan proses pemberian tugas, pengalokasian sumber daya serta pengaturan kegiatan secara terkoordinasi kepada setiap individu dan kelompok untuk menerapkan rencana yang telah ditetapkan agar tujuan bisa tercapai. Pengorganisasian berfungsi untuk memberikan atau mendistribusikan tugas atau wewenang/tanggung jawab dan sistem komunikasi serta mengkoordinasi kerja setiap bawahan di dalam suatu tim agar terorganisir dengan baik (Suprapto, 2011: 131). Pengorganisasian komunikasi menurut Suprapto (2011) juga melibatkan aspek komunikator, pesan, media, khalayak dan pengaruh yang diinginkan.

Pengorganisasian (organizing) yang dilakukan oleh Departemen Community Development Officer dalam program CSR kampung gambut berdikari PT. Pertamina RU II Sungai Pakning, dimulai dengan pengorganisasian deskripsi kerja dari masing-masing pihak yang terlibat dalam pelaksanaan program. 
Pada aspek perencanaan rancangan hingga distribusi pesan, PT. Pertamina RU II Sungai Pakning mengacu kepada hasil analisis social mapping yang telah dilakukan. Pendistribusian pesan tidak hanya dilakukan dari atas ke bawah akan tetapi juga dilakukan dari bawah ke atas. Hal ini menunjukkan bahwa PT. Pertamina RU II Sungai Pakning mengharapkan terlaksananya komunikasi ke atas (upward communications), komunikasi ke bawah (downward communications) untuk mendukung keberhasilan program yang dilaksanakan.

Dalam pelaksanaan program CSR kampung gambut berdikari ini PT. Pertamina RU II Sungai Pakning memberikan dalam bentuk pelatihan peningkatan kapasitas individu hingga pemberian fasilititas penunjang pelaksanaan program, infrastruktur dan lainnya. Dan dalam pelaksanaan program tidak hanya melibatkan masyarakat secara umum, tetapi juga menggandeng pihakpihak terkait seperti lurah atau kepala desa setempat, penyuluh pertanian, Dinas atau UPTD terkait seperti Dinas Kehutanan, Dinas Koperasi, dan lainnya.

Merujuk pada tema besar Program CSR "Kampung Gambut Berdikari” berdasarkan hasil social yang dilakukan dan ditetapkannya program Kampung Gambut Berdikari sebagai program CSR yang utama dan akan dilaksanakan. Oleh karena itu untuk menunjukkan komitmennya dalam melaksanakan program CSRnya PT. Pertamina RU II Sungai Pakning telah membentuk dua kelompok binaan untuk diberdayakan dan dikembangkan dalam mendukung program. Kelompok pertama yaitu "Masyarakat Peduli Api (MPA)" dan Koperasi tunas makmur yaitu pembentukan UMKM yang mengelola produksi makanan ringan berbahan baku utama nanas dan pengelolaan kawasan wisata arboretum.

Kelompok binaan pertama yakni Masyarakat Peduli Api (MPA) tujuan dibentuknya kelompok ini yaitu melakukan usaha-usaha lebih bersifat preventif atau pencegahan dalam kebakaran lahan dan hutan. Serta disisi lain juga memberikan pelatihan-pelatihan guna meningkatkan kapasitas masyarakat yang terlibat. Untuk mempermudah komunikasi dalam pelaksanaan kegiatan MPA, maka dibentuk sebuah yang diberi nama FORKOMPA atau Forum Komunikasi Masyarakat Peduli Api.

Kelompok binaan kedua yang dibentuk oleh PT. Pertamina RU II Sungai 
Pakning yakni Koperasi Tunas Makmur yang hingga saat ini telah memiliki anggota sebanyak 25 orang. Serta telah memiliki beberapa unit usaha berbeda yang dikelola langsung oleh kelompok. Unit usaha tersebut diantaranya ialah pertanian, pengolahan (produksi) dan arboretum. Berdasarkan kajian dan analisis yang telah dilakukan oleh PT. Pertamina RU II Sungai Pakning bahwa gambut yang merupakan jenis tanah mayoritas di Riau dan tidak semua tanaman dapat tumbuh diatasnya. Dan dapat diketahui bahwa salah satu jenis tanaman yang bisa dikembangkan pada tanah gambut tersebut, adalah tanaman buah nanas. Hingga saat ini bertani nanas masih menjadi mata pencaharian sebagian masyarakat di Sungai Pakning. Jenis nanas yang dipilih yaitu genus ananas merupakan salah satu jenis nanas yang dapat tumbuh di iklim tropis dan pada jenis tanah apapun tanpa perlu perawatan yang intensif.

Dengan melihat potensi besar tersebut CSR PT. Pertamina Sungai Pakning mencoba mengangkat sebuah kelompok petani nanas di daerah Kampung Jawa yang termasuk ring 2 CSR PT. Pertamina Sungai Pakning. Dengan menjadikannya mitra binaan dan kelompok usaha resmi yang diberi nama kelompok tani nanas "Tunas Makmur". Kelompok ini resmi dibentuk pada tahun 2017 dan diketuai oleh Bapak Samsul. Pada awalnya kelompok ini hanya beranggotakan beberapa orang laki-laki namun setelah mendapat pembinaan dari perusahaan kelompok ini mulai perlahan berkembang dengan bertambahnya wanita.

PT. Pertamina RU II Sungai Pakning melalui Kelompok Tani Tunas Makmur juga memberikan kepercayaan untuk bagi mitra guna menjadi pelopor pelestari kawasan gambut baik flora dan fauna khas yang ada di dalamnya. Salah satu usaha yang dapat dilakukan PT. Pertamina RU II Sungai Pakning adalah dengan pengembangan kawasan arboretum gambut yang mana Koperasi Tunas Makmur menjadi garda terdepan sebagai penggerak dalam rangka pengembangan wisata dan edukasi di kawasan arboretum gambut tersebut dengan dukungan penuh oleh CSR PT. Pertamina RU II Sungai Pakning.

Media yang yang digunakan oleh dalam pelaksanaan program yaitu dengan memanfaatkan media sosial baru sebagai saluran penyebaran informasi, adapun media yang digunakan oleh PT. Pertamina RU II Sungai Pakning dalam pelaksanaan program kampung gambut berdikari yaitu dengan memanfaatkan media baru sebagai 
saluran penyebaran informasi yang digunakan yaitu Instagram yang dikelola langsung oleh bidang CSR PT. Pertamina RU II Sungai Pakning, selain itu setiap kegiatan yang dilakukan dalam pelaksanan program juga akan dimuat dalam Koran dan media online.



Gambar 5.2. Proses Pengorganisasian dan Pelaksanaan Program CSR Kampung Gambut Berdikari PT. Pertamina RU II Sungai Pakning

Sumber: Olahan Peneliti, 2019

Analiss Komunikasi Departemen Community Development Officer Dalam Metode Pengawasan (Monitoring) Dan Evaluasi (Evaluating) Pelaksanaan Program CSR Kampung Gambut Berdikari PT. Pertamina RU II Sungai Pakning Kabupaten Bengkalis
Kata monitoring dan evaluasi telah menjadi kesatuan kata yang lazim dalam program pembangunan di Indonesia. Monitoring dan evaluasi juga telah menjadi bagian yang tidak terpisahkan dari sebuah program dimulai sejak formulasi 
(perencanaan), implementasi hingga evaluasi termasuk di dalamnya monitoring, pengendalian dan pelaporan sebagai instrumennya. Monitoring dan evaluasi program menjadi sangat melekat pada perencanaan komunikasi. Lewat monitoring dan evaluasi yang dilakukan akan mempermudah pemerintah dalam pengawasan dan penilaian kerja dari sebuah program yang dijalankan.

Monitoring dan evaluasi yang dilakukan oleh PT. Pertamina RU II Sungai Pakning dalam program CSR Kampung Gambut Berdikari secara umum dipimpin oleh tim CSR dan dibiasanya bersama dengan tim eksternal yakni dari perwakilan Universitas dan Pemerintah. Monitoring dan evaluasi yang dilakukan oleh perusahaan tidak hanya dilakukan oleh PT. Pertamina cabang dalam hal ini PT. Pertamina RU II Sungai Pakning akan tetapi juga dilakukan monitoring evaluasi oleh PT. Pertamina pusat satu kali setiap tahunnya. Hal ini untuk mendorong perbaikan dan perkembangan pada program yang dijalankan sehingga nantinya dapat menghasilkan output yaitu hasil kerja yang lebih maksimal. Hal ini dinyatakan oleh CDO PT. Pertamina RU II Sungai Pakning sebagaimana berikut ini.
"Kita ada monev (monitoring dan evaluasi) dibagi menjadi 2 ada monev internal dan eksternal. Untuk monev internal biasanya ini dilakukan per triwulan (3 bulan sekali) yang ikut itu dari tim CSR sendiri ada 5 CDO. Hasilnya akan ditindak lanjut di triwulan selanjutnya. Untuk monev eksternal ini monev tahunan biasanya dilakukan 1 tahun sekali. Biasanya yang melakukan tahunan ini itu nanti orang ekternal (Pertamina Dumai, Pertamina Pusat), ada juga dari kampus (universitas) kemarin itu ada dari UGM dan UMS"

Monitoring internal yang dilakukan oleh CDO dan internal PT. Pertamina RU II Sungai Pakning pada program merupakan sebuah pengawasan on going yang dilakukan pada saat program sedang berjalan ini dilakukan oleh perusahaan untuk mengetahui secara cepat dan responsif bagaimana perkembangan program ditengah-tengah masyarakat dan juga untuk menjaga fleksibilitas program. Sedangkan untuk evaluasi end review yang mencakup semua evaluasi dari awal sampai dengan akhir pelaksanaan program dan yang akan merangkum semua evaluasi ongoing dan perbaikan, sehingga bisa dijadikan pijakan dan rekomendasi untuk pelaksanaan program selanjutnya. Hal ini dilakukan lewat monitoring tahunan yang melibatkan pihak-pihak eksternal. 
Dalam pelaksanaan monitoring dan evaluasi yang diadakan oleh PT.Pertamina RU II Sungai Pakning, adapun hal-hal yang dievaluasi meliputi efektivitas dan kemajuan progres implementasi program CSR kampung gambut berdikari, bagaimana kendala atau permasalahan yang dihadapi, apa kekurangannya dan bagaimana kelebihannya, bagaimana respon masyarakat terhadap program tersebut, dan berbagai hal lainnya yang juga berfungsi sebagai bahan pertimbangan untuk membuat program CSR di tahun yang akan datang. Evaluasi program kampung gambut berdikari juga membicarakan masalah laba dan rugi program pada masyarakat, linimasa (timeline) program apakah sudah sesuai dengan perencanaan atau ada hambatan yang cukup berarti dalam pelaksanaannya.

Analisis Komunikasi Departemen Community Development Officer Dalam

Metode Pengawasan (Monitoring) Dan Evaluasi (Evaluating)

Pelaksanaan Program CSR Kampung Gambut Berdikari PT. Pertamina

RU II Sungai Pakning Kabupaten Bengkalis

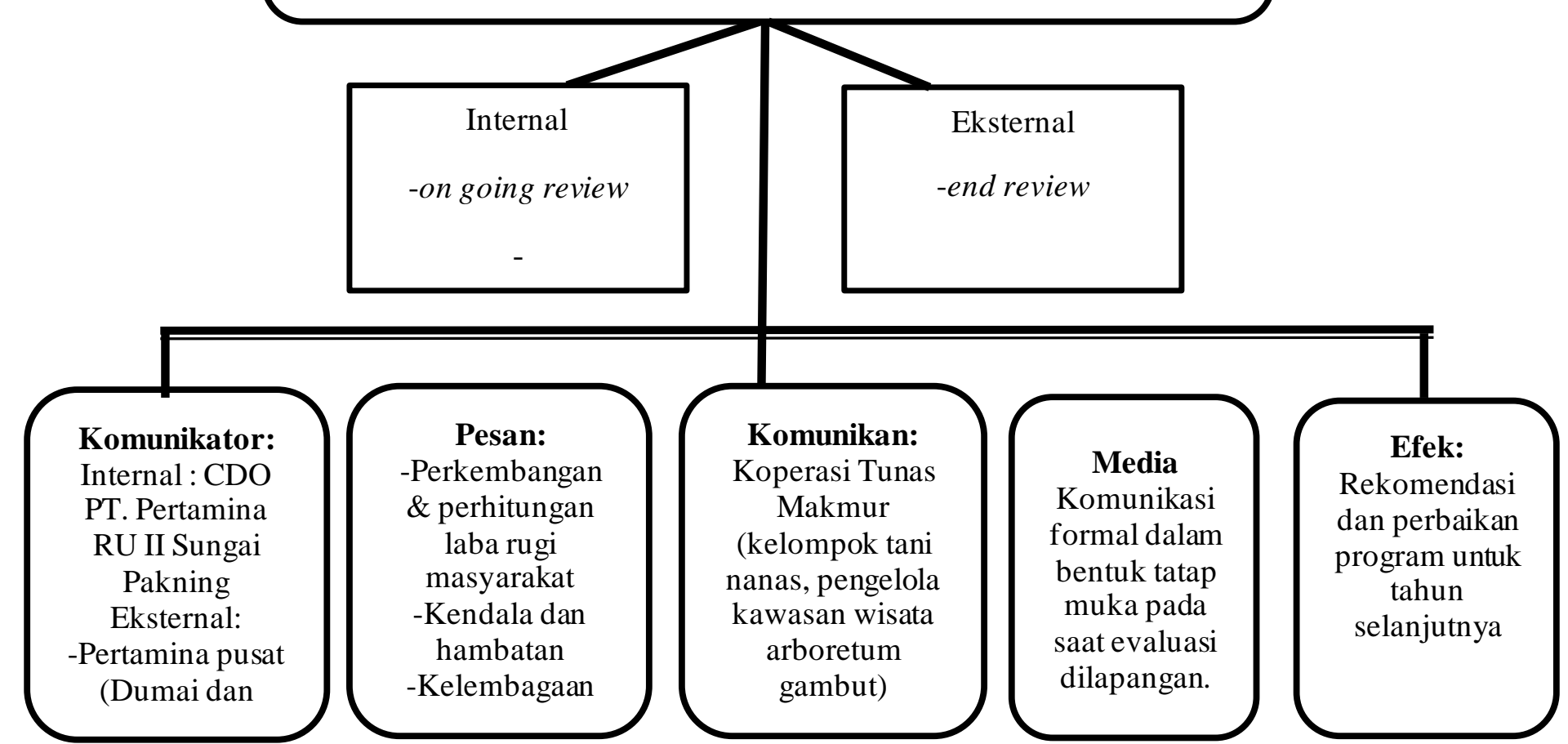

Gambar 5.3 Proses Monitoring dan Evaluasi Komunikasi Pelaksanaan Program Kampung Gambut Berdikar PT. Pertamina RU II Sungai Pakning

\section{PENUTUP}

Pada tahap perencanaan komunikasi, yang berperan sebagai komunikator secara

\section{Sumber: Olahan Peneliti, 2019}

formal adalah Pemerintah baik ditingkat daerah ataupun pusat lewat peraturan dan kebijakan CSR yang telah ditetapkan. 
Sedangkan pesan yang disampaikan adalah Undang-Undang Nomor 40 tahun 2007 tentang perseroan terbatas, Peraturan Pemerintah Nomor 47 tahun 2012 tentang tanggung jawab sosial dan lingkungan. Dan yang menjadi komunikan adalah PT. Pertamina RU II Sungai Pakning, CDO (Community Development Officer) yang disampaikan melalui media formal berupa Undang-undang dan peraturan yang telah dikeluarkan. Semua aturan dan permasalahan dilapangan mengakibatkan sebuah efek berupa dilakukannya social mapping dan penyusunan rencana kerja hingga rencana strategis dan menghasilkan output yaitu program Kampung Gambut Berdikari.

Pada tahap pengorganisasian (organizing) dan pelaksanaan (actuating) program CSR Kampung Gambut Berdikari PT. Pertamina RU II Sungai Pakning, yang berperan sebagai komunikator adalah Bidang CSR PT. Pertamina RU II Sungai Pakning, lebih tepatnya CDO (Community Development Officer). Pesan penting program CSR Kampung Gambut Berdikari disampaikan oleh CDO berisi pesan hasil analisis dan keluaran kebijakan perusahaan kepada berbagai komunikan dibagian yang berbeda-beda. Komunikan pada tahap ini terbagi menjadi beberapa bagian, yaitu masyarakat sasaran yang sesuai dengan kriteria penerima yang telah ditetapkan yakni warga miskin, pendidikan kurang, kesehatan kurang dan berada disekitar wilayah perusahaan lebih diutamanya. Pesan yang disampaikan oleh CDO disalurkan melalui media formal dalam proses monitoring dan evaluasi, juga memanfaatkan media sosial insragram CSR PT. Pertamina RU II Sungai Pakning, Koran cetak, portal berita online serta laporan kinerja tahunan. Tahap ini menghasilkan efek atau dampak yaitu pemberdayaan dan peningkatan kesejahteraan ekonomi bagi masnyarakat.

$$
\text { Pada tahap monitoring dan }
$$
evaluasi, terbagi kedalam dua jenis yaitu, monev internal dan monev eksternal. Monev internal dilakukan pada saat program berjalan (ongoing review, dan dilakukan per tiga bulan. Sedangkan monev eksternal dilakukan saat program telah melalui setahun berjalan (end review). Yang berperan sebagai komunikator di monev yakni CDO PT. Pertamina RU II Sungai Pakning. Pada monev eksternal proses pengawasan melibatkan beberapa pihak eksternal diantaranya Pertamina Pusat dan Pertamina regional (Kota Dumai), pemerintah daerah dan juga perwakilan beberapa universitas 
yang bekerjasama dengan perusahaan. Adapun pesan yang disampaikan adalah perkembangan dan perhitungan laba/ rugi masyrakarat, kendala dan hambatan yang dihadapi, harmonisasi kelembagaan hingga kesesuaian pelaksanaan dengan timeline yang direncanakan. Adapun efek yang dihasilkan dari proses monitoring dan evaluasi ini adalah adanya rekomendasi dan perbaikan program untuk tahun yang akan datang.

Sebagai saran bagi PT. Pertamina RU II Sungai Pakning untuk terus melakukan formulasi dan inovasi yang lebih baik dalam perencanaan hingga pelaksanaan program CSRnya.Bagi perusahaan/dunia usaha lainnya untuk dapat mengambil peran serta lebih memaksimalkan peran dan fungsinya dalam pembangunan dan turut serta memberdayakan dan mensejahterakan masyarakat lewat program-program CSR yang dilakukan.

\section{DAFTAR PUSTAKA}

Broom,G., \& Dozier, D (1990). Using Research in Public Relations._Upper Saddle River,NJ:Pretince Hall.

Cangara, Hafid, 2005. Pengantar Ilmu Komunikasi, Jakarta : PT Raja Grafindo

Cresswell,John. W. (1998), Qualitative Inquiry and Research Design : Choosing Among Five Traditions, London : SAGE Publications.
Dwikartini. 2009 :30, Corporate Social Responsibility-Transformasi Konsep Sustainability Managemen dan Implementasi di Indonesia.Bandung: Refika Utama

Fukuyama, F. 1999. The Great Disruption: Human Nature and the Reconstitution of Social Order. New York, London, Toronto, Sidney, Singapore: Simon and Schuster.

Kaye, Michael. 1994. Comunication Management. Sydney: Prentice Hall.

Miles, M.B., and A.M.Huberman. (1994). Qualitative data analysis. 2nd ed. Thoushand Oaks, CA: Sage.

Nursahid, 2006, Tanggung Jawab Sosial $B U M N$, Depok : Piramedi

Perkins, D. D, dan Marc A. Zimmerman. 1995. "Empowerment theory, Psychology. October 1995 Vol.23. New York.

Purnaningtyas, N. C., \& Rina, N. (2018). Perencanaan Komunikasi Program Ojek Makanan Balita (Omaba) Dalam Membentuk Persepsi Orang Tua Mengenai Anak Gizi Buruk (Studi Deskriptif Pada Orang Tua Dengan Riwayat Anak Gizi Buruk Di Kelurahan Cisaranten Kidul, Gede Bage). Commed: Jurnal Komunikasi dan Media, 2(2), 1835.

Rorong, M. J. (2019) Penempatan Teori Dalam Ilmu Komunikasi (Kajian Kepustakaan Dalam Perspektif Deductive-Interpretif). Commed: Jurnal Komunikasi dan Media, Vol.4,No.1

Soedarsono, Dewi K, 2009, Sistem Manajemen Komunikasi (teori, model dan aplikasinya).Bandung: Simbiosa Rekatama Media 
Soemanto, B. et.al. 2007. Sustainable Corporate : Implikasi Hubungan Harmonis Perusahaan dan Masyarakat. PT Semen Gresik (Persero) : Gresik.

Solihin, I. 2009. Corporate Social Responsibility From Charity to Sustainabilility. Salemba Empat : Jakarta

Sumaryo. 2009. Implementasi Tanggung Jawab Sosial Perusahaan (Corporate Social Responsibility) dalam Pemberdayaan dan Peningkatan Kesejahteraan Masyarakat : Kasus di Provinsi Lampung. Disertasi. IPB : BogorSumodiningrat, G. 1999. Pemberdayaan Masyarakat dan Jaring Pengaman Sosial. PT Gramedia Pustaka Utama : Jakarta.
Suparjan dan Hempri S. 2003. Pengembangan Masyarakat dari Pembangunan sampai Pemberdayaan. CRS Indonesia : Yogyakarta.

Suprapto, Tommy, 2011, Pengantar Ilmu Komunikasi (dan peran manajemen dalam komunikasi). Yogyakarta: CAPS.

Syahyuti. 2006. 30 Konsep Penting Dalam Pembangunan Pedesaan dan Wibisono, 2007, Membedah Konsep dan Aplikasi CSR.Gresik :Fascho Publishing.

Pertanian. PT. Bina Rena Pariwara : Jakarta Selatan

Yin, Robert. K . (1989). Case Study Research Design and Methods. Washington: COSMOS Corporations 